\title{
Enhancement of Potato Shelf Life: Role of Pre-Harvest Potassium Application
}

\author{
Zakaria Alam ${ }^{1, a}$, Md. Azizul Hoque ${ }^{2, b}$, Sanjida Akter ${ }^{3, c}$, Md. Mazadul Islam ${ }^{1, d}$, \\ Avijit Biswas ${ }^{4, e}$
}

${ }^{1}$ Tuber Crops Research Centre, Bangladesh Agricultural Research Institute, Gazipur, Bangladesh

${ }^{2}$ Department of Horticulture, Bangabandhu Sheikh Mujibur Rahman Agricultural University, Gazipur, Bangladesh

${ }^{3}$ Department of Biotechnology, Bangabandhu Sheikh Mujibur Rahman Agricultural University, Gazipur, Bangladesh

${ }^{4}$ Crop Physiology, Bangladesh Rice Research Institute, Gazipur, Bangladesh

aza.jakir@yahoo.com, bazizul@bsmrau.edu.bd, 'sanjida.bgr@yahoo.com, dmasum_ag1974@yahoo.com, eduke.biswas15@gmail.com

Keywords: Cumulative Weight Loss, Potassium Fertilizer; Storability

\begin{abstract}
An experiment was conducted at the research field in Gazipur, Bangladesh during the winter season of 2014-2015 to determine the effect of different potash fertilizer rates as pre-harvest application viz. $\mathrm{K}_{1}\left(0 \mathrm{~kg}-\mathrm{K}_{2} \mathrm{O} / \mathrm{ha}\right), \mathrm{K}_{2}\left(150 \mathrm{~kg}-\mathrm{K}_{2} \mathrm{O} / \mathrm{ha}\right), \mathrm{K}_{3}\left(175 \mathrm{~kg}-\mathrm{K}_{2} \mathrm{O} / \mathrm{ha}\right)$ and $\mathrm{K}_{4}\left(200 \mathrm{~kg}-\mathrm{K}_{2} \mathrm{O} / \mathrm{ha}\right)$ on storability of different potato varieties $\left(\mathrm{V}_{1}=\right.$ Cardinal, $\mathrm{V}_{2}=$ Courage, $\mathrm{V}_{3}=$ Diamant, $\mathrm{V}_{4}=$ Granola) under natural condition. The potato tubers were stored in a well ventilated room of day and night temperature of $\left(25-30^{\circ} \mathrm{C}\right)$ and $\left(20-25^{\circ} \mathrm{C}\right)$, respectively. Result revealed that after 135 days of storage, lowest cumulative weight loss was recorded in Granola (12.66\%) followed by Courage $(21.50 \%)$, Diamant (30.84\%) and Cardinal (30.84\%). The cumulative weight loss was minimum $(10.66 \%)$ in Granola variety after 135 days of natural storage where the pre-harvest potassium application rate was@ 200 kg- $\mathrm{K}_{2} \mathrm{O} / \mathrm{ha}$.
\end{abstract}

\section{Introduction}

Potato (Solanum tuberosum) belongs to the Solanaceae family, is a starch-rich tuberous crop and is known to be originated from the Andes of South America [5]. Worldwide production of potato is more than 376 metric tons and cultivated area is about 1,92,46,462 ha [4]. Regarding global production, the potato became the third most important food crop after rice and wheat. Asia consumes almost half of the global potato because of its huge population, although the Europeans rank first in per capita potato consumption [4]. Asia and Europe are the world's major potato producing regions, accounting for more than $80 \%$ of world production. Potato is a popular staple food in many parts of the world and an integral part of much of the world's food supply. It can produce both by true potato seed and tuber from itself. At present, Bangladesh has 400 cold storages with hardly capacity of storing 40 million MT potatoes in those cold storage. Considering the total cold storage capacity and production of potato in the country, $45 \%$ of the total produced potatoes can be preserved in the cold storages [16]. Therefore, the potato growers are bound to sell their produced potatoes in the season with low price or they preserve the tubers in the field or in the house, where they can hardly store for 2 months but quality deteriorates due to many factors like insect and pest infestation, greening of tubers etc [9]. There is an ample opportunity to work on potato storage to extend the shelf life of potato. Very limited research on potato storage is conducted in last few decades. A few researches confirmed the significant effect of potassium on potato storage $[6,15,17]$. Considering the above facts, the present study was undertaken to know the effect of potassium on natural storage ability of different potato varieties. 


\section{Material and Methods}

The field experiment was conducted at Gazipur, Bangladesh during the winter season of 20142015. The location of the experimental site was at the centre of Madhupur Tract $\left(24.09^{0} \mathrm{~N}\right.$ latitude and $90.26^{0} \mathrm{E}$ longitudes) at $34 \mathrm{~m}$ above the sea level [1]. The soil of the experimental field was silty clay of shallow Red Brown Terrace type under Salna Series of Madhupur Tract in agro ecological zone (AEZ) 28. The soil contained $\mathrm{pH}$ of $6.4[2,7]$. The breeder seed tubers were used as planting materials, which were collected from the Tuber Crops Research Center, Bangladesh Agriculture Research Institute, Joydebpur, Gazipur, Bangladesh.

Table 1. The initial physical and chemical properties of soil in the experimental field of Gazipur, Bangladesh.

\begin{tabular}{cc}
\hline Soil properties & Value \\
\hline Sand & 21 \\
Silt & 42 \\
Clay & 37 \\
Textural class & Silty clay loam \\
Particle density & $2.61 \mathrm{~g} \mathrm{~cm}^{-3}$ \\
Bulk density & $1.32 \mathrm{~g} \mathrm{~cm}^{-3}$ \\
Soil pH & 6.20 \\
Total nitrogen (\%) & 0.06 \\
Organic carbon (\%) & 0.72 \\
Available P (ppm) & 21.07 \\
Available S (ppm) & 11.02 \\
Available B (ppm) & 0.14 \\
Exchangeable K (meq 100-1 $\mathrm{g}$ soil) & 0.25 \\
\hline
\end{tabular}

Table 2. Climatological data of 2014-2015 crop season.

\begin{tabular}{|l|c|c|c|c|c|c|c|c|c|c|}
\hline \multirow{2}{*}{ Month } & \multicolumn{3}{|c|}{ Air Temperature $\left({ }^{\circ} \mathbf{C}\right)$} & \multicolumn{3}{|c|}{$\begin{array}{c}\text { Soil Temperature }\left({ }^{\circ} \mathbf{C}\right), \\
\text { Depth }\end{array}$} & $\begin{array}{c}\text { Humidity } \\
(\%)\end{array}$ & $\begin{array}{c}\text { Rain Fall } \\
(\mathbf{m m})\end{array}$ & $\begin{array}{c}\text { Evaporation } \\
(\mathbf{m m})\end{array}$ & $\begin{array}{c}\text { Ground } \\
\text { water } \\
\text { table } \\
(\mathbf{m})\end{array}$ \\
\cline { 2 - 10 } & Max. & Min. & Ave. & $10 \mathrm{~cm}$ & $20 \mathrm{~cm}$ & $30 \mathrm{~cm}$ & & & & \\
\hline November & 27.76 & 23.76 & 25.76 & 26.55 & 26.91 & 27.33 & 85.66 & 0.00 & 55.06 & 17.56 \\
\hline December & 24.80 & 16.58 & 20.69 & 22.72 & 23.17 & 23.56 & 90.70 & 5.19 & 208.15 & 17.32 \\
\hline January & 22.32 & 11.53 & 16.93 & 18.85 & 19.34 & 19.84 & 89.81 & 0.00 & 1.37 & $*$ \\
\hline February & 27.31 & 13.24 & 20.28 & 20.03 & 20.45 & 20.83 & 87.66 & 0.00 & 3.60 & $*$ \\
\hline March & 32.58 & 20.68 & 26.63 & 23.53 & 23.97 & 24.42 & 83.94 & $*$ & 4.03 & $*$ \\
\hline
\end{tabular}

*Data not recorded

Source: Meteorological Station, BSMRAU, Salna, Gazipur.

\section{Treatments and Experimental Design}

The plastic racks were used to store the tubers in a well-ventilated room of day and night temperature of $\left(25-30^{\circ} \mathrm{C}\right)$ and $\left(20-25^{\circ} \mathrm{C}\right)$, respectively and not allowed to enter light in the room. In field condition, the experiment having two factors with randomized complete block design (RCBD) of three blocks. For establishing more statistical power, blocking was also maintained in storage experiment.

The experiment consisted of four potato varieties (Cardinal, Courage, Diamant and Granola) and four potassium rates $\mathrm{K}_{1}\left(0 \mathrm{~kg}-\mathrm{K}_{2} \mathrm{O} / \mathrm{ha}\right), \mathrm{K}_{2}\left(150 \mathrm{~kg}-\mathrm{K}_{2} \mathrm{O} / \mathrm{ha}\right), \mathrm{K}_{3}\left(175 \mathrm{~kg}-\mathrm{K}_{2} \mathrm{O} / \mathrm{ha}\right)$ and $\mathrm{K}_{4}$ (200 kg- $\left.\mathrm{K}_{2} \mathrm{O} / \mathrm{ha}\right)$. A 4x4 factorial combination was laid out in RCBD replicated three times. 


\section{Recommended fertilizer rate:}

Full doses of cow dung (10 t/ha), TSP (220 kg/ha), Gypsum (120 kg/ha), Boric acid (6 kg/ha) and half doses of Urea $(175 \mathrm{~kg} / \mathrm{ha})$ were applied at final land preparation. The rest half doses of Urea (175 kg/ha) were applied as top dressings at 30 DAP followed by earthing-up and light irrigation.

\section{Measurements}

Haulm pulling was done before 8 days of harvesting for hardening of tuber and setting up of skins of tubers. The harvesting of tuber was done on February 28, 2015, when all plants reached physiological maturity stage. After harvesting, five $\mathrm{kg}$ apparently medium sized (diameter of $28-55 \mathrm{~mm}$ ) tubers from each treatment was stored in well ventilated insect proof wooden rack under diffused light on March 01, 2015. Randomly selected plants' tuber (around 500gm) were sliced into $1-2 \mathrm{~cm}$ cube per each plot were dried in oven at $80^{\circ} \mathrm{C}$ for 72 hours and calculated the dry matter $(\%)$ by the formula [3]:

$$
\text { dry matter }(\%)=(\text { dry weight } / \text { fresh weight }) \times 100 .
$$

The cumulative weight loss (\%) of stored tuber was measured at 15 days' interval. The measurement parameter: weight loss due to diseases and pest attack (dry rot and soft rot) during storage. The information on days to start sprouting (Days after storage) and days to start shriveling (Days after storage) was also recorded. When more than 5 percent of the potatoes in any lot have any sprout or cluster of sprouts more than $1 / 4$ inch in length at shipping point, more than $1 / 2$ inch in length at destination was named as starting of sprout [20].

\section{Statistical analysis}

The collected data were analyzed by the software Genstat 18th edition [21]. Two-way randomized block ANOVA was performed for this experiment. The analysis was also performed to see the block effect. The p-value $>0.05$, the block effect was not considered. The Pearson correlation was tested to see the correlation between the measurements. The correlation matrix will show the results of the correlation.

\section{Results and Discussions}

\section{Dry matter content of tuber (\%)}

Data on dry matter content of different potato varieties is presented here in Figure 1. Result revealed that there was a significant different $(\mathrm{P}<0.001)$ in dry matter content of tuber among the varieties. The highest dry matter content was recorded in the variety Cardinal $(25.56 \%)$ among the other varieties. The lowest dry matter content was recorded in the variety Granola $(20.63 \%)$. There was no significant effect of potassium application on dry matter content of tuber as the average dry matter content was 23.28(\%). Lalitha et al. [14] and Sujata et al. [22] reported that the increased potassium application can increase the dry matter content of tuber. In contrast, high dry matter content was found in low potassium application $[11,19]$. Explanations for these disagreement could be the excessive application of $\mathrm{N}, \mathrm{P}$ fertilizer and differences in environment. Because the potassium influences the water content of the plasma volume and affect water content of storage organs. Furthermore, $\mathrm{K}$ concentration in tuber above $2 \%$ lead to above normal water content and lower the dry matter content in tuber [12]. 


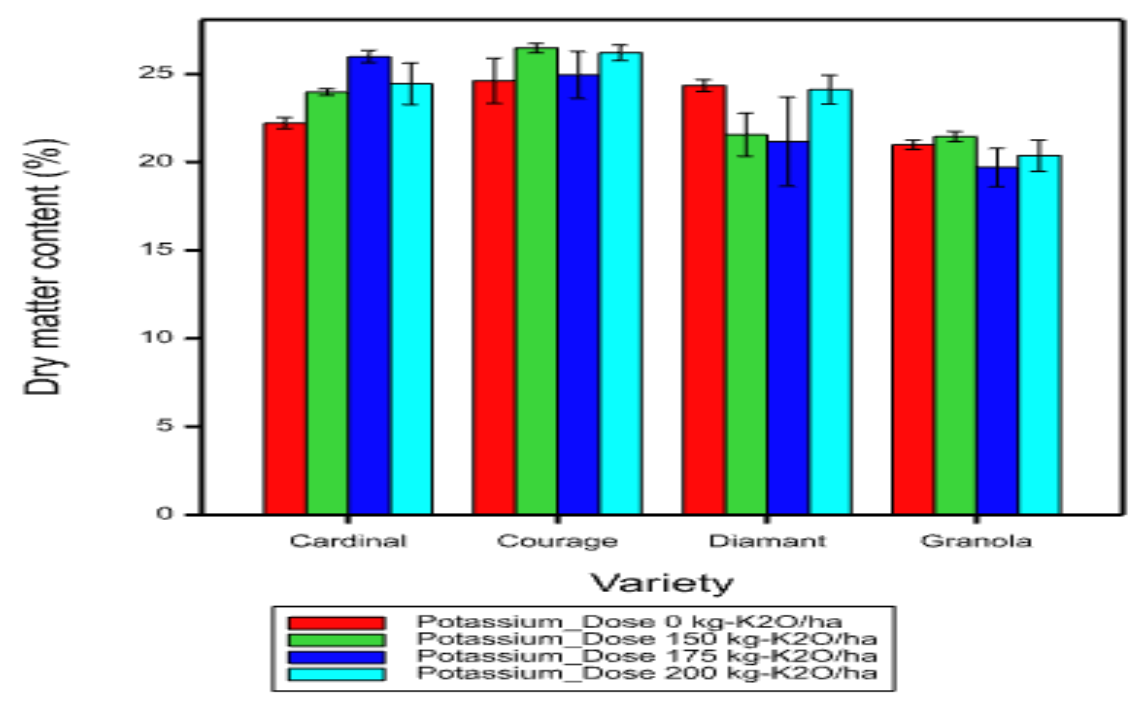

Figure 1. Dry matter content of different potato varieties (Cardinal, Courage, Diamant and Granola) in combination with four potassium doses i.e. $\mathrm{K}_{1}\left(0 \mathrm{~kg}-\mathrm{K}_{2} \mathrm{O} / \mathrm{ha}\right), \mathrm{K}_{2}\left(150 \mathrm{~kg}-\mathrm{K}_{2} \mathrm{O} / \mathrm{ha}\right)$, $\mathrm{K}_{3}\left(175 \mathrm{~kg}-\mathrm{K}_{2} \mathrm{O} / \mathrm{ha}\right)$ and $\mathrm{K}_{4}\left(200 \mathrm{~kg}-\mathrm{K}_{2} \mathrm{O} / \mathrm{ha}\right)$.

\section{Cumulative weight loss (\%) of stored tuber at 15 days' interval}

Results on cumulative weight loss (\%) of stored tuber of different varieties at different days after storage (DAS) are presented in Figure 2. Hoque [9] also found the maximum cumulative weight loss in the variety Cardinal and the minimum cumulative weight loss in the variety Granola in natural storage, which agrees with this result.

Data on cumulative weight loss (\%) of stored tuber at different doses of potassium in different days after storage (DAS) are presented in Figure 3. The minimum weight loss was found in dose of $150 \mathrm{~kg}-\mathrm{K}_{2} \mathrm{O} / \mathrm{ha}$ at 15 days interval. The weight loss was increased with the increasing rate of potassium rates. Sharma \& Sud [18] found similar result as $150 \mathrm{~kg} \mathrm{~K} / \mathrm{ha}$ rate reduces the tuber weight loss during storage. Kolbe et al. [13] found that the increasing rate of potassium fertilizer increases the tuber weight loss during storage.

The interaction effect $(\mathrm{P}<0.001)$ of potato variety and potassium dose at 135 days after storage (DAS) total weight loss (\%) of stored tuber are presented in Figure 4. It is revealed that the lowest amount of tuber weight loss was found in the treatment combination of $\mathrm{V}_{4} \mathrm{XK}_{4}(10.66 \%)$ which fits with the findings of Haddad et al. [6]. It is already proven that the high dose of potassium improves the storage ability of potato tuber by accumulating high dry matter content and reducing pest and diseases attack [10]. Furthermore, the potassium plays an important role in reduction of catalase and peroxidase enzymes' activity which leads to the less storage losses of tubers [17].

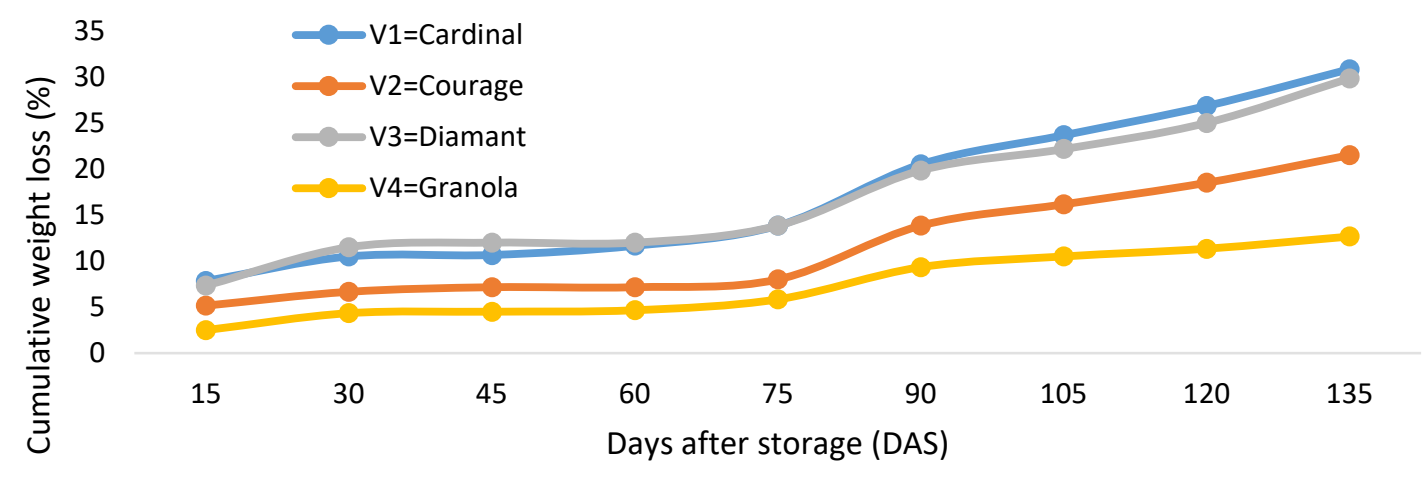

Figure 2. Cumulative weight loss of different potato varieties at 15 days interval. 


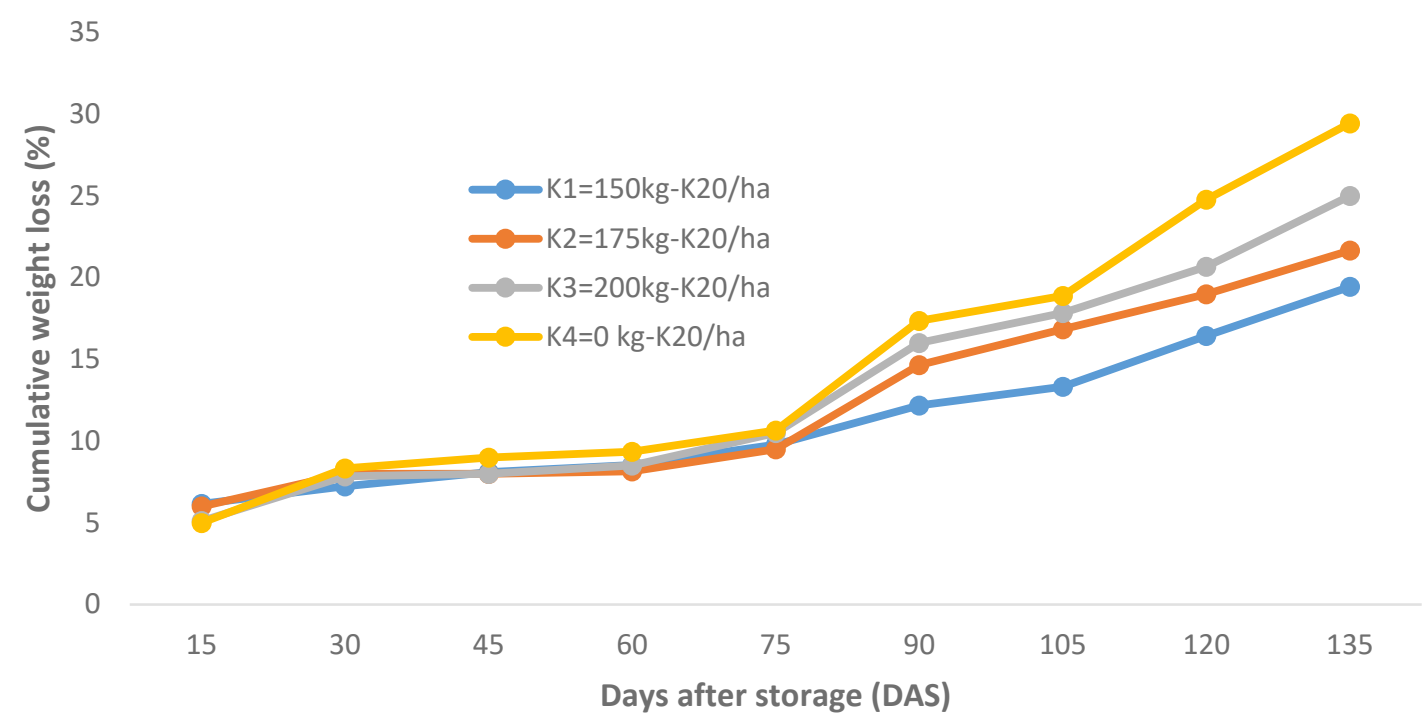

Figure 3. Effect of potassium on cumulative weight loss of potato at 15 days' interval.

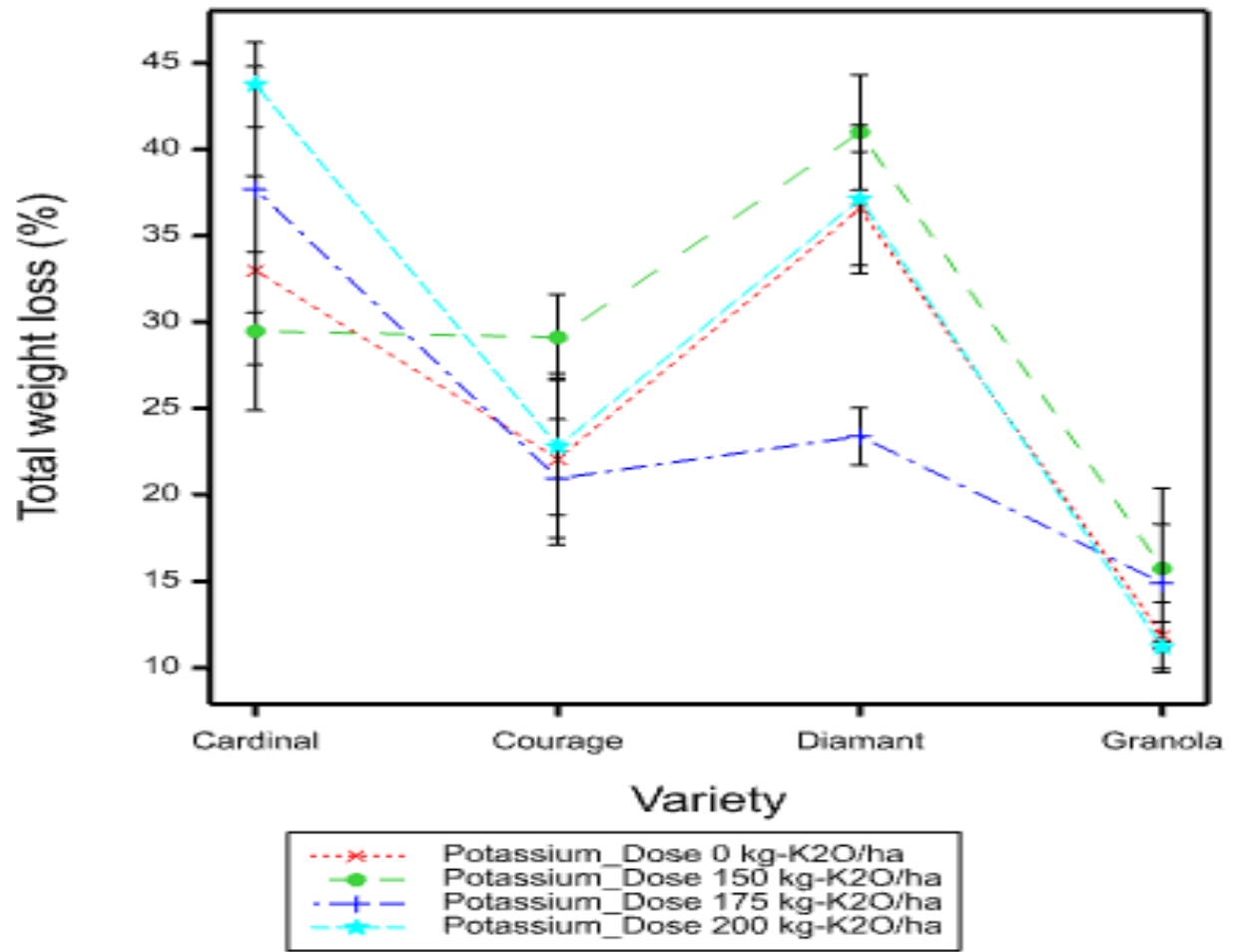

Figure 4. Combination effect of variety and potassium doses on cumulative weight loss of potato at 135 Days after storage (DAS).

\section{Days to start sprouting}

Regarding the result, there was a significant difference $(\mathrm{P}<0.001)$ in sprouting behaviour of stored tuber in case of variety (Fig. 5). The highest days to start sprouting was recorded in variety Courage (53 days) and Granola (52 days). There was no significant effect of potassium application on stored tuber sprouting and the average days to start sprouting was (47 days). The potassium is important for activation of enzymes to energy utilization, starch synthesis, $\mathrm{N}$ metabolism, and respiration and these enzymes are situated on the growing points such as meristematic tissues where the cells are dividing and primary tissues are forming and the experiment was carried out in $10-12^{\circ} \mathrm{C}$ temperature [8]. 


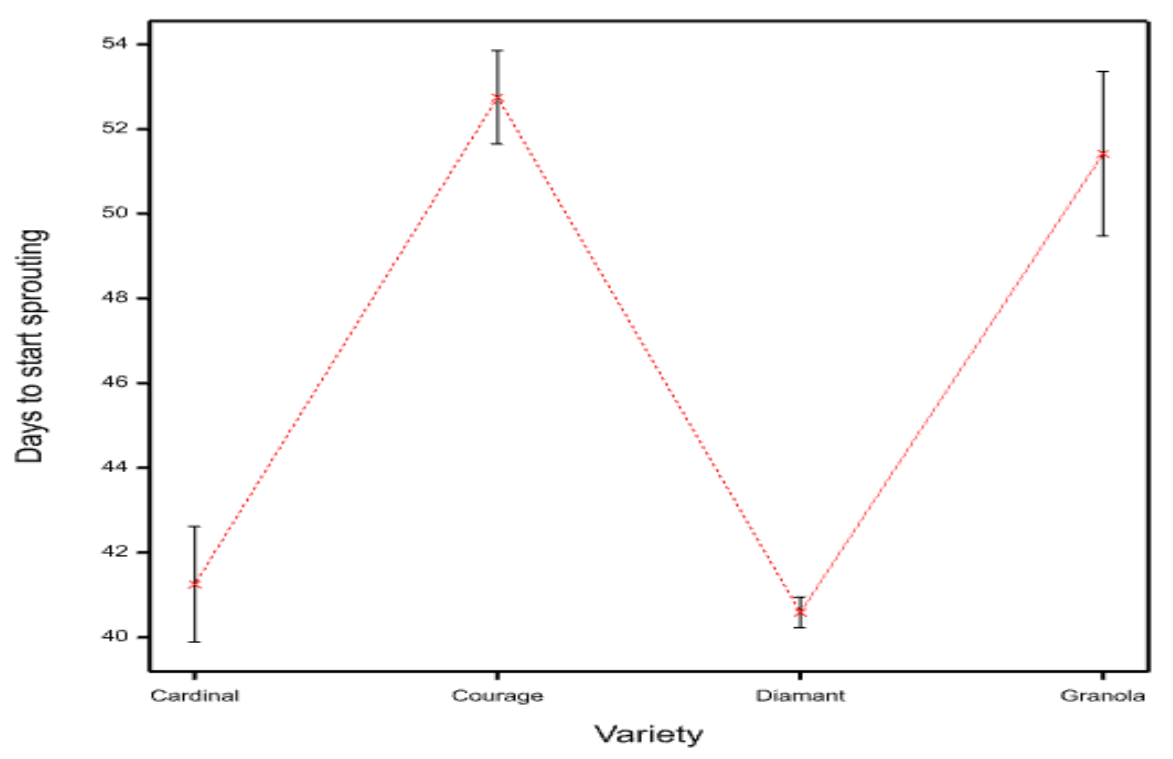

Figure 5. Effect of varieties on tuber sprouting.

\section{Days to start shriveling}

Interaction effect of variety and dose had shown the significant difference $(\mathrm{P}<0.001)$ in shrivelling behaviour of stored tuber (Fig. 6). Highest days taken to start shrivelling in combination of all potassium doses and variety Granola and all the cases it was more than 120 days. There was no significant effect of potassium application on shrivelling of stored potato.

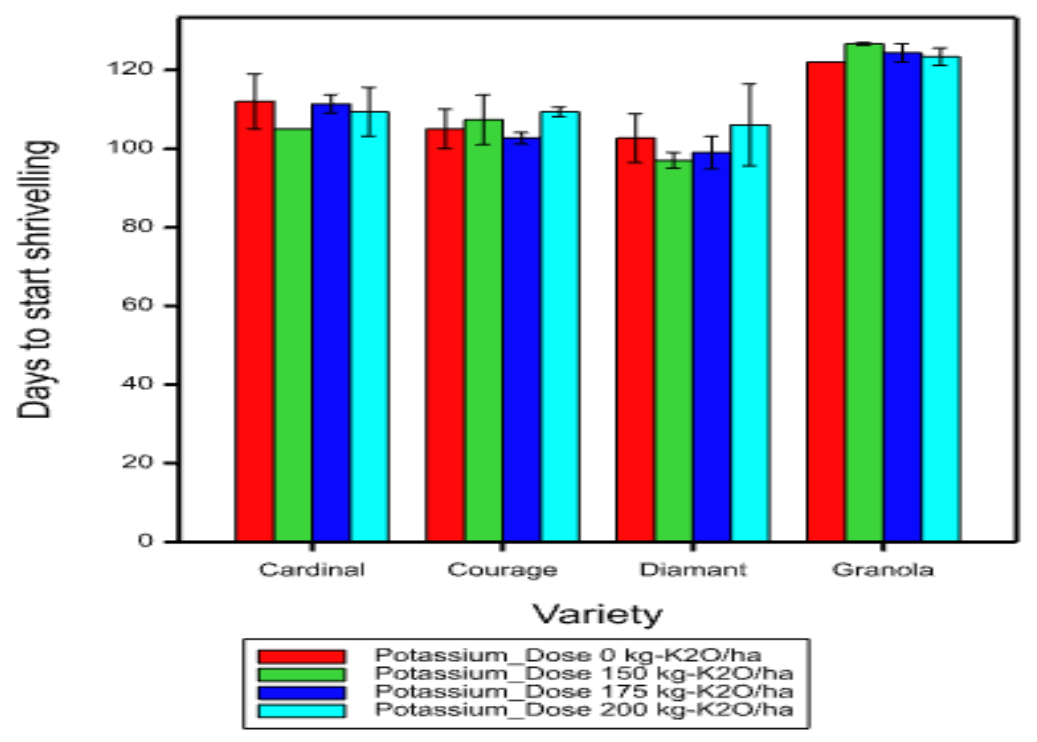

Figure 6. Days to start shriveling of different potato varieties in combination with four different potassium doses.

\section{Correlations}

In Pearson correlation (Fig. 7), there were negative correlations of the dry matter content of tuber with both the days to start shrivelling and total weight loss (\%). There was also a strong negative correlation was found between days start sprouting and total weight loss (\%). It is known that high dry matter content of tuber contains less moisture on it. The less moisture content of tuber results in less weight loss of stored tubers due to evaporation in normal temperature. The less weight loss means the more tuber is stored in storage because the rotten tubers were discarded at each 15 days interval. If the remaining stored tuber is more, the sprouting will be more. We can conclude that the dry matter content affects the total weight loss of stored tuber. 


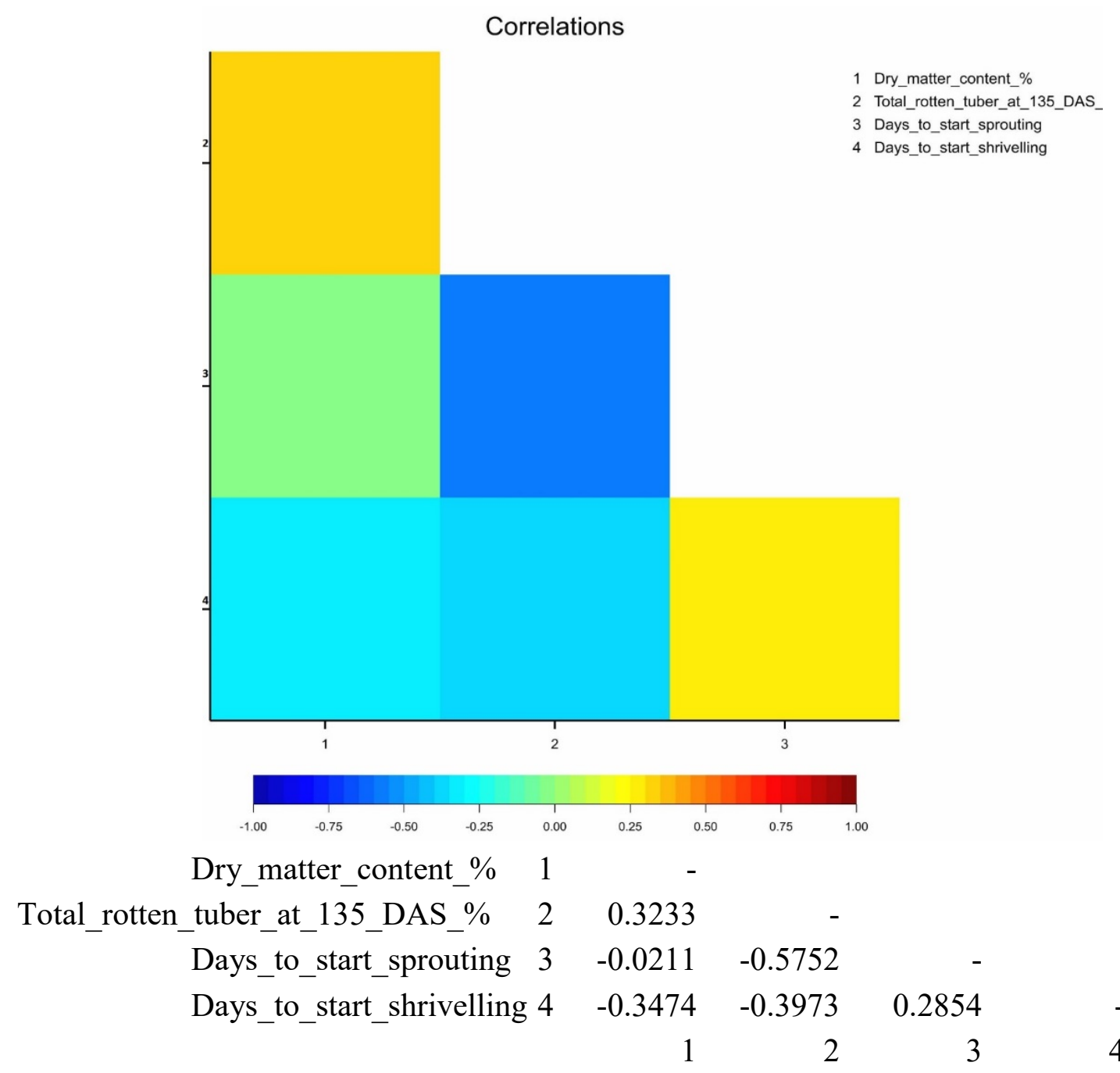

Figure 7. Heatmap of the Pearson correlation coefficient for the four measurements of 48 observation within three blocks. A red or orange color indicates positive correlation whereas blue color indicates a negative correlation. A two sided correlation matrix table is presented below the figure.

\section{Conclusion}

The result of present study generated some information which may help on efficient potato storage in natural condition. Storability of Granola variety was maximum among the examined varieties of potato. Generally, farmers apply $50-80 \mathrm{~kg} \mathrm{~K} 2 \mathrm{O} / \mathrm{ha}$ on their field, which increases the storage loss of tuber. The study revealed that the application of potassium oxide fertilizer around 150 $\mathrm{kg} / \mathrm{ha}$, improve the dry matter content as well as the natural storage ability of potato up to three and half months.

\section{Acknowledgements}

I am grateful to my supervisor who helped me a lot during my research. I want to give a big thanks to donor of my experiment, RMC Project. I would like to thank all of my co-authors, who helped me a lot during my work. 


\section{References}

[1] Anonymous. 1995. Agro-cliamatolocal data. Agromet division, Bangladesh Meteorological Department, Joydebpur, Gazipur.pp.35-65.

[2] Anonymous. 1998. Year Book of Agricultural Statistics of Bangladesh, 1996-97. Bangladesh Bureau of Statistics, Govt. of the people's Republic of Bangladesh, Dhaka, Bangladesh.

[3] CIP, 2007. Available: https://research.cip.cgiar.org/redlatinpapa/reunion_1/files/ Cooperators\%20Guide\%20protocolos.pdf

[4] FAO, 2018. Available: http://www.fao.org/potato-2008/en/world/

[5] FAOSTAT, 2018. Available: http://www.fao.org/faostat/en/\#home

[6] M. Haddad et al., Effect of different potassium nitrate levels on yield and quality of potato tubers, Journal of Food, Agriculture \& Environment. 14(1) (2016) 101-107.

[7] J. Haider, T. Marumoto, A.K. Azad, Estimation of microbial biomass, carbon and Nitrogen in Bangladesh soils, Soil Sci. Tech. 20 (1991) 643-653.

[8] J.L. Havlin et al., Soil fertility and fertilizers: An introduction to nutrient management. Vol. 515 (2005) pp. 97-141, Upper Saddle River, NJ: Pearson Prentice Hall.

[9] M.A. Hoque, Final Report on "Increasing storability of potato in natural storage and income generation through small scale processing of potato" project. Tuber crops Research Sub Centre, BARI, Munshiganj and KGF, BARC Campus, Dhaka, 2011.

[10] P. Imas, S. K. Bansal, (1999, December). Potassium and integrated nutrient management in potato, in: Global conference on potato, Vol. 611.

[11] P.D. Jenkins, S. Mahmood, Dry matter production and partitioning in potato plants subjected to combined deficiencies of nitrogen, phosphorus and potassium, Annals of Applied Biology. 143(2) (2003) 215-229.

[12] E.A. Kirkby, W. Bergmann (Eds.), Nutritional Disorders of Plants. Gustav Fischer Verlag, 1992. Zeitschrift für Pflanzenernährung und Bodenkunde. 156(4) (1993) 377.

[13] H. Kolbe et al., Effects of nitrogen, phosphorus and potassium fertilizer treatments on weight loss and changes in chemical composition of potato tubers stored at $4 \mathrm{C}$, Potato Research. 38(1) (1995) 97-107.

[14] B.S. Lalitha et al., Economics of potassium and sulphur levels on yield and quality of potato (Solanum tuberosum L.) raised from seed tuber and true potato seed (TPS). Mysore Journal of Agricultural Sciences, Communications Centre, University of Agricultural Sciences, Bangalore, India. 34(1) (2000) 61-65.

[15] P.J. Martin-Prevel, Physiological processes related to handling and storage quality of crops. In: Proceedings of the 21 st IPI Colloquium on: Methods of K Research in Plants, held at Louvainla-Neuve, Belgium, 19-21 June 1989. International Potash Institute, Bern, Switzerland, 1989, pp. 219-248.

[16] H.C. Mohanta, Bangladeshe alu sangrakkhaner bartaman obostha (In Bengali), in: Training Manual on Post Harvest Research Protocol of Potato. USAID Horticulture Project, CIP/AVRDC, Bangladesh, 2014, pp. 36-37.

[17] S. Perrenoud, Fertilizing for high yield of potato. IPI bulletin 8. Second edition, International Potash Institute, Basel, Switzerland, 1993, pp. 138-186.

[18] R.C. Sharma, K.C. Sud, Potassium management for yield and quality of potato, in: Proceedings of an Intentional Symposium on the role of potassium in nutrient management for sustainable crop production in India. International Potash Institute, Basel, 2001, pp. 363-381. 
[19] S.K. Singh, S.S. Lal, Effect of potassium nutrition on potato yield, quality and nutrient use efficiency under varied levels of nitrogen application. Central Potato Research Station, Patna801 506, Bihar, India, 2012.

[20] USDA, 2011. Available:

https://www.ams.usda.gov/sites/default/files/media/Potato_Standard\%5B1\%5D.pdf

[21] VSN International, 2015. Available: https://www.vsni.co.uk/

[22] N.T. Sujata, K.S. Krishnappa, M. Chandregowda, Dry matter accumulation, primary nutrient content and uptake in potato in relation to fertility levels, Mysore J. Agril. Sci. 35(2) (2001) 108-114. 